\title{
LITERATUROZNAWSTWO
}

Agnieszka Baczewska-Murdzek

DOI $10.15290 / \mathrm{sw} .2017 .17 .01$

Uniwersytet w Białymstoku

Wydział Filologiczny

Instytut Filologii Wschodniosłowiańskiej

tel. +48857457450

e-mail: agbacz@wp.pl

\section{Tragikomedia absurdu. Elżbieta Bam Daniiła Charmsa (reminiscencje na marginesie Procesu Franza Kafki)}

Słowa kluczowe: Charms, wolność, totalitaryzm, absurd egzystencji, strach

Wśród rosyjskich dramaturgów pierwszej połowy XX wieku, zakotwiczonych w eksperymencie otwierających go dziesięcioleci ${ }^{1}$, Daniił Charms ${ }^{2}$ (właściwie Daniił Iwanowicz Juwaczow, 1905-1941) zajmuje pozycję szczególną. Na czym owa wyjątkowość polega? Nie na tym przecież, że w zasadzie jego twórczość trafia do rosyjskiego widza i czytelnika około pół wieku po tym, jak autor Staruchy (Cmapyxa, 1939) nadaje swym dziełom formę ostateczną. Zwalczanie literatury awangardowej w Rosji Radzieckiej na przełomie lat 20. i 30. było bowiem zjawiskiem powszechnym ${ }^{3}$.

1 O kondycji dramatu tego czasu czytaj np. [Żak 2008, 6]. Szerzej na temat eksperymentu w teatrze rosyjskim patrz [Gracla 2001].

2 Daniił Charms to najbardziej rozpowszechniony spośród kilkudziesięciu (przynajmniej 40) używanych przez twórcę pseudonimów, który został podniesiony do rangi oficjalnego nazwiska. Wiadomo, że autor Elżbiety Bam najpierw dopisał go ołówkiem w dowodzie osobistym, nadając swemu nazwisku w podpisie formę Juwaczow-Charms, a później prawnie imię zmyślone zalegalizował. Szczegółową analizę pseudonimów Charmsa prezentują w jednym ze swych artykułów Jewgienija Ostrouchowa i Feliks Kuwszynow. Patrz [Остроухова, Кувшинов 2003, 230-245].

3 Podobnym represjom podlegali też m.in. pozostali oberiuci - „grupa rosyjskich artystów skazanych przez totalitarny system na niebyt za życia i artystyczną niepamięć po śmierci" [Kireńczuk 2008, 3]. 
$\mathrm{Na}$ awangardowej scenie miejsce wyjątkowe zapewnia sobie Charms ${ }^{4}$, jako przedstawiciel rosyjskiej literatury modernizmu, dzięki artystycznemu eksperymentowi, jaki pozwala uznać go za jednego z prekursorów w Rosji teatru absurdu ${ }^{5}$, zjawiska, którego nazwa po raz pierwszy pojawia w pracy Martina Eslina The Theatre of the Absurd (1961) [Eslin 1961] w odniesieniu do sztuk powstałych w teatrze zachodnioeuropejskim u schyłku pierwszej połowy wieku $\mathrm{XX}^{6}$.

Jak słusznie konstatuje Aleksandr Kobrynski:

Хармс - вместе со своим другом Введенским стал родоначальником литературы абсурда, которая представляет собой не тотальное отсутствие смысла, а наоборот - иной, не укладывающийся в обыденную ло-

Dzieła Charmsa natomiast, także te, które zostały opublikowane jeszcze za jego życia, znajdowały się w Rosji Radzieckiej w całkowitym zapomnieniu do początku lat 60., kiedy to wydany został jego zbiorek wybranych dziecięcych wierszy Gra (Игра, 1962). Odtąd, przez około 20 kolejnych lat, próbowano Charmsa przedstawiać wyłącznie jako autora radosnej twórczości dla dzieci, animatora dziecięcych zabaw, wesołka, budując tym samym obraz twórcy pozostający w całkowitej sprzeczności z jego „dorosłymi” dokonaniami. W Rosji miano jednego z głównych reprezentantów rosyjskiego literatury pięknej lat 20.-30. opozycyjnej wobec oficjalnej literatury radzieckiej Charms zyskał dopiero w połowie lat 90. XX wieku. Na zachodzie, a dokładniej w RFN, dzieła zebrane Charmsa, przygotowane w oparciu o jego ocalałe rękopisy, publikowane były od 1978 roku.

4 Charms brał aktywny udział w życiu artystycznym Sankt-Petersburga. Nawiązywał współpracę z licznymi ugrupowaniami literackimi. W 1925 r. poznał Aleksandra Trufanowa, od którego przejął później manierę wyzywającego ubierania się. W grupie poetyckiej Trufanowa Charms poznał Wwiedienskiego, Lipowskiego i Druskina, z którymi stworzył grupę „Czinari”. Jesienią 1927 roku wraz z kilkoma innymi poetami założył pozostającą w kręgu oddziaływania poetyki surrealizmu grupę - „OBERIU „,(..) jako nowy oddział lewej sztuki" [Drawicz 1991, s. 14]. Lewa równoznaczne było dla Oberiutów z określeniem awangardowa i oznaczało futurystyczną skłonność do prowokacji, irracjonalizmu i eksperymentu w przestrzeni nowego języka poetyckiego, dadaistycze upodobanie do tworzenia cyrkowej atmosfery podczas występów publicznych, fascynację literaturą absurdu i czystego nonsensu. Ekscentryk Charms uwielbiał szokować również w życiu pozaliterackim, które było dla niego nieustającym, świadomie odgrywanym spektaklem. Artysta przechadzał się po Leningradzie w stroju Sherlocka Holmesa z fajką w zębach. W kawiarniach pijał ze srebrnych pucharów, które przynosił ze sobą w teczce. A kiedy pisał, na drzwiach wywieszał kartkę: „Mam pilną pracę. Jestem w domu, ale nikogo nie przyjmuję. Nawet nie rozmawiam przez drzwi." [Глоцер, online].

5 Jak słusznie zauważa Wiktor Woroszylski „Obecnie uważa się oberiutów za prekursorów europejskiego teatru absurdu (przykładem - sztuka Charmsa Elżbieta Bam, grana i opublikowana w Polsce wcześniej niż w Rosji, gdzie autor za życia i długo po śmierci objęty był kategorycznym zakazem druku)". Zob. [Woroszylski 1994, 25].

6 Chodzi tu o Eysa śpiewaczkę Eugene Ionesco (prapremiera - rok 1950, publikacja 1952 r.) i Czekajac na Godota Samuela Becketa (którego pierwsze wystawienie i publikacja mają miejsce w roku 1953). Oba utwory powstały w 1949 roku. „Pierwsze wydanie The Theatre of the Absurd Martina Esslina ukazało się w 1961 roku, a więc jego praca miała $\mathrm{w}$ dużym stopniu charakter rekonesansu, intuicyjnego niemal rozpoznania obcego terenu na podstawie najbardziej rzucających się w oczy i niekiedy dość chaotycznie notowanych cech". Zob. [Krajewska 1999, 226]. 
гику смысл, разрушающий, как правило, устоявшиеся логические связи [Кобринский 2009, 416-417].

Zainteresowanie tak rozumianym absurdem wyraża się w większości dzieł Charmsa adresowanych do dorosłego czytelnika ${ }^{7}$, czemu od końca lat 80. XX wieku coraz więcej uwagi poświęcać zaczyna krytyka literacka i teatralna ${ }^{8}$. Przy czym najpełniej realizuje się owo Charmsowskie upodobanie do kreowania światów pełnych alogizmów w skrzącej owymi niedorzecznościami właśnie, programowej dla jego koncepcji teorii absurdu ${ }^{9}$, sztuce Elżbieta Bam (Елизавета Бам, 1927).

Punktem wyjścia w utworze i jego sceną finałową zarazem (dramat ma bowiem budowę kolistą ${ }^{10}$ ) jest scena dobijania się do drzwi tytułowej bohaterki dwóch mężczyzn, którzy, jak się dalej wyjaśni, przyszli ją aresztować za niepopełnioną zbrodnię. Napisany na zlecenie literackiej sekcji OBERIU dramat jest wyraźnym nawiązaniem do wydanego dwa lata wcześniej w Austrii Procesu (Der Prozess, 1914) Franza Kafki. Oba dzieła zaczynają się

7 Warto nadmienić, że z względu na działalność cenzury przez długie dziesięciolecia Charms istniał w świadomości czytelnika rosyjskiego wyłącznie jako autor literatury dziecięcej o zacięciu pedagogicznym. W latach 1928-1941 stale współpracował on z dziecięcymi czasopismami Jeż (Еж), Czyżyk (Чиж), Świerszcz (Сверчок), Zuchy (Октябрята), pismami redagowanymi m.in. przez S. Marszaka, N. Olejnikowa i J. Szwarca. Wydał 20 książek dla dzieci, w których da się już zauważyć charakterystyczną dla jego twórczości skłonność do podejmowania gry z czytelnikiem. Jednak sam twórca, co często podkreślają badacze jego literackich dokonań, utworom adresowanym do dzieci większego znaczenia nie przydawał, albowiem pisane były one przez niego wyłącznie z przyczyn pragmatycznych. Patrz np. Злобина [online], Жаккар [1995, 23].

8 I tak na przykład Walerij Sażyn zwraca uwagę na wszechobecną w twórczości Charmsa absurdalność, jako zasadę kreowania nie tyle obrazu jednostki, ile wizji całych społeczeństw [Сажин 1985, 58], Dmitrij Tokariew stwierdza, iż w polu twórczego zainteresowania dramaturga znajdują się sytuacje dziwne i alogiczne: „Хармс интересовался, без сомнения, абсурдом, его привлекали нелепые, странные, иллогические ситуации" [Токарев 2002, 25], natomiast Władimir Głocer podkreśla, że tym, co miało największy wpływ na strategię absurdu w dziełach Charmsa były groza i potworności otaczającej go rzeczywistości: „все ужасы жизни, все ее нелепости стали не только фоном, на котором разворачивается абсурдное действо, но и в какой-то мере причиной, породившей самый абсурд, его мышление" [Глоцер 1988, 131].

9 „Elżbieta Bam stała się wizytówką Charmsa. Dla pozostałych członków OBERIU często bywała źródłem i punktem odniesienia" [Duda 2010, 75].

10 Kolista kompozycja dramatu pozwala uwypuklić sytuację uwięzienia Elżbiety Bam w kręgu absurdu. Klamra spajająca utwór zamyka przestrzeń nadając jej w pewnym sensie postać labiryntu. Koło to labirynt doskonały. Wędrówka po jego obwodzie byłaby przecież nieskończona. A zatem metafora zaczarowanego kręgu obłędu jaką posłużył się Charms staje się znaczeniowo tożsama z przestrzenią labiryntu, w którym znalazł się bohater Procesu. Zarówno jedno, jak i drugie przedstawienie charakteryzuje bowiem swego rodzaju zamknięcie i ograniczenie. W tym kontekście motyw labiryntu może być elementem wspólnym dla obu literackich przedstawień, z których wyłania się absurd. 
sceną niedorzecznego aresztowania. W obydwu dwaj przedstawiciele bliżej nieokreślonej władzy podejmują próbę dokonania zamachu na wolność osobistą. I wreszcie w obu długo nikt nie zna przesłanek, na podstawie których ma odbyć się zatrzymanie rzekomego przestępcy.

Czego mieli dopuścić się Elżbieta Bam i Józef K. zdają się nie wiedzieć nie tylko oni sami, lecz także dokonujący ich zatrzymani przedstawiciele państwa opresyjnego. Jakie okoliczności decydować miały o niezbędnym zatrzymaniu w obu literackich jego przedstawieniach nie dowiadują się ani pokrzywdzeni bohaterowie absurdalnych zajść, ani też widz i czytelnik utworów Charmsa i Kafki. W naznaczonym absurdem świecie wewnętrznym Elżbiety Bam i Procesu, gdzie to nie prawo wyznacza reguły działania władzy, a władza owa manipuluje nim w imię własnych potrzeb, bezpodstawne aresztowanie staje się ostatecznie faktem.

I choć w obu przypadkach do zatrzymania dochodzi w równie niedorzecznych okolicznościach, choć oba zajścia podobnie pozbawione są sensu, uzasadnienia i usprawiedliwienia, ich przebieg nie jest do końca jednakowy.

Irracjonalne zdarzenia, o jakich czytamy w powieści Kafki, na tym jeszcze etapie mają charakter statyczny. Rzecz, dla której nie znajdujemy żadnej racji, rozgrywa się w Procesie o poranku i naznaczona jest senną atmosferą chwili tuż po przebudzeniu. Wysłannicy tajemniczej władzy wkraczają w przestrzeń prywatną pokoju Józefa K., nie posuwając się póki co do przemocy fizycznej. A sam bohater wydaje się tym najściem wyraźnie zaskoczony. Urzędnik bankowy uważa je co najwyżej za nieporozumienie lub niedorzeczny żart kolegów. Jest on przekonany, że wszystko da się szybko wyjaśnić i nie widzi na tym etapie powodu by się bronić. Józef K. jeszcze nie wie do czego zdolna może być władza, a i ona sama nie nazbyt jeszcze okrzepła.

Sytuacja aresztowania Elżbiety Bam, które inaczej niż u Kafki nie jest tylko wstęp do właściwego Procesu, a głównym motywem dramatu Charmsa, rozwija się bardziej dynamicznie. Po pierwsze, ograniczenie wolności przedstawione przez rosyjskiego dramaturga odbywa się z użyciem siły fizycznej. Sprawcy pozbawionego sensu zatrzymania, by go dokonać, po próbach zastraszenia Bam słowem („Elżbieta Bam, otwierać, bo inaczej sami wyważymy" ${ }^{11)}$, starają się wyłamać drzwi do pomieszczenia, w którym się ona schroniła

11 Д. Хармс, Елизавета Бам, [в:] Д. Хармс, Цирк Шардам, Санкт-Петербург 1999, c. 144. W tym i kolejnych przytoczeniach, jeśli nie zaznaczę inaczej, tłumaczenie moje $[\mathrm{ABM}]$. 


\section{Первый:}

Ломай.

Второй

У Вас ножа нету?

\section{Первый}

Нет, Вы плечом. [Хармс 1999, 114]

Po wtóre, przepełniona strachem bohaterka nieusprawiedliwionego niczym najścia (nikt jej o charakterze popełnionych rzekomo przestępstw ciągle nie informuje) podejmuje próbę oporu. Ucieka przed oprawcami, byle dalej od tragicznych w skutkach efektów ich popartych jedynie argumentem siły poczynań (przez moment myśli nawet o wyskoczeniu przez okno), by wreszcie zamknąc się w ostatnim pomieszczeniu, które znalazło się na jej drodze ku wolności, o którą wtedy jeszcze panicznie walczy (a przynajmniej chce mieć na nią nadzieję).

Сейчас, того и гляди, откроется дверь и они войдут... Они обязательно войдут, чтобы поймать меня и стереть с лица земли. Что я наделала! Что я наделала! Если б я только знала... Бежать? Но куда бежать? Эта дверь ведет на лестницу, а на лестнице я встречу их. В окно? (Смотрит в окно). Ууу, высоко! мне не прыгнуть! Ну что же мне делать?.. Э! чьи-то шаги! Это они. Запру дверь и не открою. Пусть стучат, сколько хотят. [Хармс 1999, 114]

Skąd strach ${ }^{12}$, który odczuwa, skąd przekonanie, że absurdalny pościg, w którym wyznaczono jej rolę zwierzyny łownej nie jest ani żartem, ani nawet koszmarną pomyłką? Otóż Elżbieta Bam, inaczej niż Józef K., od samego początku wydaje się dobrze wiedzieć w jakiej nierzeczywistości przyszło jej żyć, do czego zdolna jest tamtejsza władza, która jak mówi o niej sama bohaterka „nie ma sumienia” ${ }^{13}$. Elżbieta ma świadomość, że w świecie ugruntowanego już absurdu, który ją zewsząd otacza, nie trzeba być winnym, by przyszła kara, do której wstępem jest brutalne zatrzymanie. Na chwilę co prawda zapomina o tym, władzy skutecznie udaje uśpić się jej czujność, by wykorzystać w pełni moment zaskoczenia ${ }^{14}$ (co bohaterka sobie później zresztą wyrzuca, nie zabezpiecza się bowiem przez to należycie przed

12 O obecności zjawiska strachu i jego funkcjach w twórczości Daniiła Charmsa patrz szerzej [Шульпяков 2013, 40]. O motywie strachu w dramacie Elżbieta Bam czytaj więcej [Кусовац 2016, online].

13 Do jednego z funkcjonariuszy, którzy przyszli ją właśnie aresztować bohaterka dramatu Charmsa mówi: „увы, но у Вас нет совести”. [Хармс 1999, 116]

14 Schemat represyjnego postępowania władzy wobec obywateli opisanego w Elżbiecie Bam państwa bezprawia, z góry bowiem zakłada wykorzystanie sytuacji zaskoczenia, 
spodziewanymi represjami15), ale w głębi duszy i tak przecież dobrze wie, że jeżeli najwyższa instancja wysyła po nią swoich przedstawicieli, to jej los jest już przesądzony.

Skąd takie przekonanie? Otóż, po pierwsze, inaczej niż u Kafki, pewna już swej pozycji władza nie stara się nawet zataić swojego autorytarnego charakteru. „I tak Pani przed nami nie ucieknie” [Хармc 1999, 116] mówią Elżbiecie wprost przy pierwszej próbie jej zatrzymania funkcjonariusze państwa opresyjnego. Po wtóre, bohaterka dramatu, wyraźnie wyposażona została w wiedzę, jaką posiadał sam Daniił Charms, prześladowany przez stalinowski terror, osadzony na więziennym oddziale psychiatrycznym ${ }^{16}$, gdzie ostatecznie umarł z głodu podczas oblężenia Leningradu. To dlatego, świadoma manipulacji jakich przedstawiciele czynników rządowych się dopuszczają, Elżbieta wita ich okrzykiem: „Mamo! Chodź tutaj! Kuglarze przyjechali!" ${ }^{17}$. I po trzecie wreszcie, kiedy do aresztowania ma dojść ostatecznie i nieodwołalnie, przedstawiciele rzekomego prawa, tak przynajmniej twierdzą o sobie oni sami

\section{Пётр Николаевич}

Именем закона Вы арестованы. [Хармс 1999, 145]

wspaniałomyślnie decydują się jednak wyjawić Elżbiecie, jakiego bezprawnego czynu miała się rzekomo dopuścić. Wtedy to właśnie, w finałowej scenie utworu, okazuje się, iż bohaterka dramatu przez cały ten czas oskarżana jest o zabójstwo Piotra Nikołajewicza Kupernaka, tego samego, który przyszedł ją właśnie aresztować. A zatem ma odpowiadać za to, czego z oczywistych powodów zrobić nie mogła ${ }^{18}$.

о czym władza owa ustami swych przedstawicieli informuje oficjalnie: „Прошу как следует вслушаться в мои слова. Я хочу доказать Вам, что всякое несчастие наступает неожиданно". [Хармс 1999, 127]. Jak słusznie zauważa ksiądz Józef Tischner tego typu władza bowiem przede wszystkim „zmierzała do tego, by człowieka demaskować, poniżać, wyłapywać słabości”. [Starczak-Kozlowska 1994, 46]

15 Owo zapomnienie brzemienne jest w tragiczne skutki. Elżbieta Bam zostaje ostatecznie schwytana i poprowadzona w majestacie rzekomego prawa na śmierć.

16 O historii traktowania szpitali psychiatrycznych w Rosji nie jako miejsca terapii chorych, lecz jako przestrzeni, gdzie środki przymusu bezpośredniego stosowane są wobec osób zdrowych czytaj więcej [Grzywacz 2015, online].

17 „Мама! Пойди сюда! Фокусники приехали!” [Хармс 1999, 120], [zaznaczenie moje $\mathrm{ABM}]$.

18 Mroczną wizję zniewolenia ujął bowiem autor Elżbiety Bam w fabułę, którą trudno uporządkować dlatego między innymi, iż ścisłe związki przyczynowo-skutkowe przestają $\mathrm{w}$ niej istnieć. W typowy dla teatru absurdu sposób rozwój tradycyjnie rozumianej akcji zastępuje w dziele absurdysty pogłębiona refleksja. Więcej na temat naruszenia zależności przyczynowo-skutkowej w dramacie Charmsa patrz [Жаккар 1995, 218-221]. 
Elżbieta jest więc postacią tragiczną, cierpiąca ze względu na „nierozumność" otaczającej ją rzeczywistości, która jest dla niej i obca, i wroga zarazem, ale też udręczona jest z powodu samej świadomości istnienia wokół niej świata, w którym rzekome dowody oparte są na nonsensownych przesłankach, bo władza manipuluje faktami i relatywizuje prawdę dla własnych potrzeb.

$\mathrm{W}$ finałowej scenie mamy do czynienia z ironicznym przerysowaniem, a zarazem zachwianiem naturalnego porządku rzeczy. Paradoks i mimowolny choć czarny humor ${ }^{19}$ wynikają tu z faktu, iż w stworzonym przez Charmsa świecie przestają nagle dziać prawa logiki, które w oparciu o nasze życiowe doświadczenie każą nam wierzyć, że ktoś raz zabity nigdy nie powstanie $\mathrm{z}$ martwych, nawet powołany przez najwyższą władzę do wypełnienia najbardziej niecierpiących zwłoki obowiązków służbowych czy jakiejkolwiek „odpowiedzialnej misji” ${ }^{20}$.

Daniił Charms odwołuje się w scenie zatrzymania do prześmiewczych sposobów satyrycznego obrazowania świata, sięga po hiperbolę, ironię, a nawet groteskę, by niedorzeczność represyjnego wobec Bam świata bardziej jeszcze uwypuklić.

Scena szalonego pościgu, którego uczestnikami stają się Elżbieta Bam, potencjalna aresztowana, i dwóch podejmujących próbę jej zatrzymania przedstawicieli „prawa”, nabiera z czasem wyraźnie nonsensownego charakteru $^{21}$. To, co miało być początkowo walką o życie, starciem pomiędzy siłami dobra i zła, przeradza się z czasem w niby niewinną dziecięcą grę, $\mathrm{w}$ niedorzeczną tak naprawdę zabawę $\mathrm{w}$ berka, przypominającą komedię slapstickową błazenadę z jej nieodłącznym elementem - groteskowo nieporadnymi stróżami prawa ${ }^{22}$.

19 Pojęcia tego używam w artykule w rozumieniu jakie proponuje Joseph Twadell Shipley, który określa czarny humor jako „humor ujawniający przedmiot swojej zabawy poprzez niszczenie wartości moralnych, wywołujących mroczny uśmiech". Zdaniem autora Dictionary of World Literary Terms, Forms, Technique, Criticism czarny humor, wraz z cynicznym podejściem i otwartą walką, jest sposobem reagowania na zło i absurdalność życia. [Shipley 1979]

20 „на ответственное дело”. [Хармс 1999, 117]

21 „ДАНИИЛ ХАРМС - поэт и драматург, внимание которого сосредоточено не на статической фигуре, но на столкновении ряда предметов, на их взаимоотношениях. В момент действия предмет принимает новые конкретные очертания, полные действительного смысла. Действие, перелицованное на новый лад, хранит в себе «классический отпечаток» и в то же время - представляет широкий размах обэриутского мироощущения". [Бахтерева, online].

22 Gdy jednak weźmiemy po uwagę, iż ganiany skończyć się ma śmiercią osoby złapanej, po raz kolejny możemy przekonać się, iż w Elżbiecie Bam mamy do czynienia z charaktery- 


\section{Иван Иванович}

Ха-ха-ха. (Бежит за Петром Николаевичем.)

Где же дом?

\section{Елизавета Бам}

Тут вот, за этой чёрточкой.

\section{Пётр Николаевич}

(хлопает Ивана Ивановича)

Ты пятнашка!

\section{Елизавета Бам}

Иван Иванович, бегите сюда!

\section{Иван Иванович}

Ха-ха-ха, у меня ног нет!

\section{Пётр Николаевич}

А ты так, на четверинках! [Хармс 1999, 125-126]

Dwuznaczność i paradoksalność tej sceny wzbogacone zostają w karnawałowy śmiech i beztroską na pierwszy rzut oka klaunadę.

Chcąc uzmysłowić czytelnikowi irracjonalny charakter całego zajścia, by ośmieszyć bezzasadną procedurę, Charms prowadzi swych bohaterów ponadto w kierunku zdziecinnienia (stróże bezprawia z radością stają się przecież uczestnikami dziecięcej gry), recenzując tym samym poczynania władzy, jako działania infantylne i pozbawione jakiejkolwiek logiki. Postępujące zdziecinnienie przedstawicieli organów państwowych, które objawia się w dramacie również „brakiem dystansu, niecierpliwością, rozhamowaniem i zdenerwowaniem z błahego powodu" [A. Jęsiak, M. Harciarek, online $]^{23}$

stycznym, zwłaszcza dla opowiadań Charmsa, przejawem czarnego humoru. Komentując obecność tej odmiany komizmu w twórczości prozatorskiej Charmsa Aleksander Aleksandrow pisze: „Об исчезновениях и смертях рассказывается с жутковатым смешком. Без жалости”. I dalej: „Юмор - обязательный конструктивный элемент произведений Хармса. Но это черный юмор в его хрестоматийных образцах" [Александров 1991, $21,25]$. Siergiej Borisow natomiast analizując obecność humorystycznych przedstawień rzeczy tragicznych, wydobywania pierwiastka humoru z zestawienia elementów grozy i absurdu w twórczości Charmsa zauważa: „Смерть, причем насильственная и жестокая, подается автором лишь как повод для забавы. (...) игры со смертью” Д. Хармса были достоянием узкого круга его друзей и стали известны широким кругам читателей лишь в начале 1990-х годов. [Борисов 2007, 101].

23 Współczesna neuropsychologia identyfikuje takie zachowania, jako objawy otępienia czołowo-skroniowego, tj choroby neurodegrdacyjnej charakteryzującej się postępującymi zmianami osobowości i zachowania, które coraz bardziej zbliżają chorych do poziomu trzyletniego dziecka. Obserwacje psychiki ludzkiej poczynione przez Charmsa prawie 100 lat wcześniej pozwalają zatem doszukiwać się związków jego literackiej działalności z zainteresowaniami surrealistów, zwracających szczególną uwagę i na zaburzenia psychiczne dorosłego człowieka, i na mentalność dzieci, a także sugerować mogą, iż twórca opisując sytuację absurdalnego zatrzymania przedstawia ją jako efekt zaburzeń psychicznych osób go dokonujących. Por. [L. Carol, L. Armstrong 2014, t. 2]. 
ujawnia dramaturg dodatkowo pozwalając dokonującemu właśnie zatrzymania funkcjonariuszowi państwa represyjnego, jak małemu chłopcu, znudzić tym, co właśnie robił i raptownie oddalić z posterunku zupełnie jakby ten opuszczał miejsce prywatnego spotkania.

\section{Иван Иванович}

Если позволите, Елизавета Таракановна, я пойду лучше домой. Меня ждёт жена дома. У ней много ребят, Елизавета Таракановна. Простите, что я так надоел Вам. Не забывайте меня [Хармс 1999, с. 12].

Zjawisko piętrzącego się wokół Bam absurdu budowane jest, jak wynika z powyższego przytoczenia, również poprzez irracjonalne zachowanie agresora, stosowanie przez dopuszczającą się właśnie naruszenia „miru domowego" postać zasad dobrego wychowania. Nienaganne maniery oraz wyjątkowa uprzejmość Iwana Iwanowicza, który nie tylko brutalnie wkracza w prywatną przestrzeń domu rodziny Bam, ale też jeszcze chwilę wcześniej grozi Elżbiecie śmiercią, stoją w sprzeczności z jego realnym działaniem. Zważywszy na okoliczności w jakich ujawniają się owe przejawy „taktu” i grzeczności, słowa prześladowcy wydają się i niedorzeczne, i śmieszne zarazem. Podobnie jak fakt, że podejmujący kolejną próbę zatrzymania podejrzanej Iwan Iwanowicz w trakcie wykonywania czynności, będących przecież działaniami opresyjnego organu procesowego, wtedy właśnie prawi Elżbiecie komplementy.

\section{Иван Иванович}

У Вас чрезвычайно приятная внешность" [Хармс 1999, 120].

Podobne sytuacje są tyleż komiczne, co jednak zatrważające. Analizowana scena przywodzi na myśl, doskonale łączące w sobie oba te aspekty, rosyjskie humoreski. Dramaturg wykorzystał zręcznie tradycje literatury rosyjskiej epok minionych, korzystając zwłaszcza z osiągnięć Mikołaja Gogola, by odwołując się do siły jego „gorzkiego śmiechu” pokazać bezsens działania totalitarnej władzy.

Kwintesencją absurdu w mrocznej wizji osaczenia, do tego przecież sprowadza się przedstawione przez Charmsa aresztowanie, staje się scena, gdy dokonujący zatrzymania funkcjonariusze, w efekcie swoich irracjonalnych działań i na prawach absurdu rządzących światem, którego są oni częścią, sami ostatecznie znajdą się w sytuacji odosobnienia.

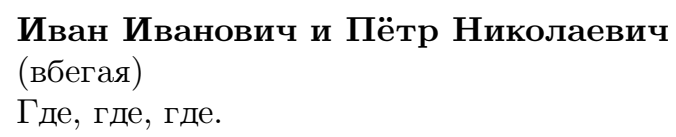


Елизавета Бам,

Елизавета Бам,

Елизавета Бам.

\section{Пётр Николаевич}

Тут, тут, тут.

\section{Иван Иванович}

Там, там, там.

\section{Пётр Николаевич}

Где мы оказалися, Иван Иванович?

\section{Иван Иванович}

Пётр Николаевич, мы с Вами взаперти.

\section{Пётр Николаевич}

Что за безобразие! Прошу меня не тыч! [Хармс1999, 122-123].

Groteskowość przedstawienia wynika tu z niepostrzeżenie zaistniałej zamiany podmiotu działającego w przedmiot własnego działania (oto oprawca, nieoczekiwanie dla samego siebie i obserwatorów z zewnątrz, przeradza się w postać ponoszącą konsekwencje planowanych represji). Obaj funkcjonariusze, wykonujący przecież czynności procesowe, bardziej niż policjantów przypominają cyrkowych clownów. Chcąc zrobić dowcip komuś, sami padają ofiarą swojego „żartu”. Charms kreuje zatem postaci, które, okazują się doskonale wpisywać w tradycje literackiej burleski.

W przypadku licznych odczytań twórczości Kafki badacze nie są do końca zgodni co do tego, czy metafora autora Procesu dotyczy proroczej wizji ${ }^{24}$ "Niemiec hałaśliwego Hitlera", jak powie wiele tak później o III Rzeszy Nabokov [Nabokov 1971, 221], czy raczej aparatu biurokracji ${ }^{25}$ monarchii austrowęgierskiej, z którym osobiście zetknął się sam pisarz, a może jest to nasycona pierwiastkiem religijnym opowieść o grzechu pierworodnym ${ }^{26}$. Wielorakim interpretacjom spuścizny praskiego powieściopisarza sprzyja znaczny stopień uogólnienia i umowności, z jakim spotykamy się w mrocznej przestrzeni naszkicowanych jego piórem historii ${ }^{27}$. I chociaż Charms, podobnie jak czeski pisarz, tworzy dzieło pozbawione szczegółowych opisów

24 „Cała proza Kafki jest w jakimś sensie przewidzeniem faszyzmu” [Płoski, Kobos, online]. „,... w «Procesie» można dopatrywać się proroczej wizji fingowanych procesów znanych z historii dwóch totalitaryzmów, «brunatnego» i «czerwonego». [Tatarkiewicz 2009, online].

25 „Kafka jest pisarzem biurokracji, jest bodaj najwnikliwszym pisarzem opisujaccym mechanizmy biurokratyczne we wszystkich możliwych wcieleniach". [Markowski 2015, online].

26 Taką interpretację dzieła Kafki proponują m.in. Małgorzata Bogaczyk-Vormayr [Bogaczyk-Vormayr 2014, 21-22,27], Agnieszka Budrecka [Budrecka 2014, 343-344].

27 Jak słusznie zauważa Edward Kasperski: „Istnieją ku temu także inne racje. Idea „definitywnej interpretacji” jest przejawem logicznego błędu zwanego contradictio in adiecto, 
czasu i miejsca akcji, nadając mu tym samym wymiar uniwersalny, inaczej niż Kafka, wysyła równocześnie do czytelnika sygnały świadczące o tym, że ma jednak na myśli pewien konkretny absurd, znienawidzoną nierzeczywistość, w której pojedyncze ludzkie istnienie nie przedstawia sobą żadnej wartości.

Odniesienia do sytuacji stalinowskiego terroru pojawiają się w sztuce pod postacią pojedynczych słów, które autor przemyca od czasu do czasu wkładając w usta swych bohaterów. Są to, opisujące szczególne relacje międzyludzkie radzieckiej przestrzeni społeczno-politycznej, czasowniki użyte w typowej dla tych stosunków formie liczby mnogiej (my, wy) w odniesieniu do pojedynczej osoby, poparte od czasu do czasu zwrotem towarzyszu, towarzysze.

Uważny czytelnik w stworzonym przez dramaturga uniwersum absurdu jest w stanie dopatrzeć się elementów prawdy historycznej. Zdolny jest odczytać sugestię autora, by opisany w dziele świat konfrontować z realiami kraju Sowietów. W Charmsowskiej wizji niedorzecznego aresztowania może doszukać się aluzji do fali zatrzymań i procesów (kończących się prawie zawsze wyrokami śmierci) i innych masowych represji, która przetoczyła się przez Rosję Radziecką w latach 1918-192128.

Nie dziwi zatem fakt, że Charms, by pokazać swój krytyczny stosunek do konkretnej, historycznie prawdziwej niestety przestrzeni, proponuje czytelnikom i widzom wymowną groteskową metaforę drewnianego domku na wzgórzu, w którym króluje karaluch i współrządzące z nim myszy.

Стоит избушка - деревянный домик,

в избушке светит огонёк,

на огонёк слетаются черницы,

стучат в окно ночные комары.

Порой шмыгнет и выпорхнет под крышей

разбойник старый козодой,

собака цепью колыхает воздух

и лает в пустоту перед собой,

а ей в ответ невидные стрекозы

ponieważ natura interpretacji dopuszcza ich wielość, a zatem wyklucza pojawienie się interpretacji, która ucina proces interpretowania. Interpretacja ostateczna równałaby się po prostu unicestwieniu interpretacji. Dążenie do unieruchomienia procesu interpretowania jest także sprzeczne z funkcjonowaniem literackiej sztuki słowa, która realizuje się, jak wiadomo, w indywidualnym odbiorze, a ponadto wyraża się w inwencji oraz w żywej i świeżej percepcji". [Kasperski 2008, 19]

28 Więcej na temat sytuacji społeczno-politycznej w Rosji Radzieckiej tego okresu patrz np. [Figes, 2008]. 
бормочут заговор на все лады.

(...)

Никто в нём не живёт

и дверь не растворяет,

в нём только мыши трут ладонями муку,

в нём только лампа светит розмарином

да целый день пустынником сидит на печке таракан [Хармс 1999, 136-137].

Ten, na pierwszy rzut oka idylliczny, obrazek przedstawia jednak miejsce odrażające. Zamieszkana przez wstrętne insekty przestrzeń wyraźnie naznaczona jest brakiem wolności i śmiercią. Obecne w mrocznym świecie myszy bezwolnie wykonują bezsensowne, ale zlecone im zadania. Zniewolony pies, wiernie służący obrzydliwemu panu, rozpartemu na piecu karaluchowi, poprzez swe nieskoordynowane ruchy doprowadza natomiast do unicestwienia wszelkiego życia. Jego łańcuch, jak zabójczy nóż, przecina powietrze, niszcząc tym samym jedyną strukturę, w której jakiekolwiek życie jest możliwe. Tak opisaną przestrzeń ${ }^{29}$ przenika dodatkowo niegasnące nigdy światło lampy, która świeci tradycyjnie odnoszonym do rytuału pogrzebowego rozmarynem ${ }^{30}$.

Ta groteskowa wizja nieomal jednoznacznie wymierzona zostaje przeciwko tyranii Stalina, który rękoma swych najbliższych współpracowników

29 Taka koncepcja naznaczonego piętnem śmierci totalnie absurdalnego świata Rosji Radzieckiej rządzonego przez karalucha, któremu zaślubione zostaje (rozmaryn kojarzony bywa z uroczystością zaślubin) na zasadzie całkowitego poddaństwa całe jego otoczenie stanie się impulsem do powstania innego wybitnego dzieła literatury rosyjskiej. W 1933 odnosząca się do postaci Józefa Stalina metafora karalucha zostanie rozwinięta w wierszu Osipa Mandelsztama Mьъ живем, под собою не чуя страны w utworze, który przypieczętował tragiczny los poety, przynosząc jego autorowi śmierć:

Мы живем, под собою не чуя страны,

Наши речи за десять шагов не слышны,

А где хватит на полразговорца,

Там припомнят кремлевского горца.

Его толстые пальцы, как черви, жирны,

И слова, как пудовые гири, верны,

Тараканьи смеются глазища

И сияют его голенища.

А вокруг него сброд тонкошеих вождей,

Он играет услугами полулюдей.

Кто свистит, кто мяучит, кто хнычет,

Он один лишь бабачит и тычет.

Как подкову, дарит за указом указ -

Кому в пах, кому в лоб, кому в бровь, кому в глаз.

Что ни казнь у него - то малина

И широкая грудь осетина. [Мандельштам 1994, 74]

30 Szerzej na temat symbolu rozmarynu patrz [Kopaliński 1988, 999]. 
doprowadza w naznaczonym piętnem śmierci kraju do zaniku wszelkiej wolności i sprawiedliwości. Jak tragicznie jego rządy kończą się dla każdego pojedynczego ludzkiego istnienia przekonuje się czytelnik Elżbiety Bam, gdy w chwilę po aresztowaniu tytułowej bohaterki, jej oczom ukazuje się groteskowo-przerażającą postać karalucha, który, w zmienionej już pozie, czeka w domku na wzgórzu na swą ofiarę, tym razem jednak już ,z toporem w rękach" [Хармc 1999, 146] gotów w każdej chwili pozbawić swą ofiare życia.

I chociaż przedstawiciele władzy przystępując do aresztowania informują zatrzymywaną, że kwestię jej winy rozpozna sąd

\section{Первый}

Вы обвиняетесь в убийстве Петра Николаевича Кру пернак.

Второй

И за это Вы ответите.

Елизавета Бам

Да я не убивала никого!

Первый

Это решит суд.

\section{Елизавета Бам}

Я в вашей власти [Хармс 1999, 145].

mimo, iż skutecznie przekonana do tego ofiara niedorzecznych zajść, sama oddaje się w ręce obiecanej jej sprawiedliwości, wszystko wskazuje na to, że sugerowanej przez aresztujące ją osoby rozprawy sądowej nie będzie. Wyrok już przecież zapadł¹, a kat z niecierpliwością czeka już tylko na jego wykonanie. Inaczej niż Józef K. Elżbieta Bam Procesu zatem nie doczeka.

Obie ukazane w artykule kreacje relacji władza - jednostka, gdzie rządzący nie licząc się z pojedynczym ludzkim istnieniem, z naruszeniem prawa realizują własne cele i interesy powoduje, iż zarówno dramat Charmsa jak i powieść Kafki nabierają cech filozoficznych traktatów o wolności, o jej utracie, o absurdalnym ubezwłasnowolnieniu, stając się jednocześnie głosem sprzeciwu wobec działań każdej władzy, która dąży do totalnego podporządkowania sobie pojedynczej ludzkiej egzystencji. I o ile daleko posunięta umowność świata przedstawionego dzieła Kafki sugeruje jego wielorakie interpretacje, w przypadku sztuki Charmsa mamy z pewnością do czynienia

31 Łatwo tu o analogię z pracą organów śledczych współczesnej Charmsowi Rosji. „Dajcie mi człowieka, a znajdę na niego paragraf" - ta zasada stalinowskiego prokuratora generalnego, a potem szefa MSZ i ambasadora w USA Andrieja Wyszyńskiego, najwierniejszego pomocnika Stalina, która jeszcze w latach 80 . była metodą pracy wielu prokuratorów w krajach realnego socjalizmu. O Andrieju Wyszyńskim i zasadach rządzących działaniami najbliższych współpracowników Stalina więcej [Frołow 2016, nr 24, online]. 
z wystąpieniem przeciwko totalitaryzmowi, autokratycznej nierzeczywistości „niewolonych i niewolących, którzy tworzyli totalitarny system miażdżący miliony ludzi" [Garlicki 2008, online], z krytyką poczynań konkretnego „ojca narodu”, przywódcy współczesnego twórcy Elżbiety Bam państwa totalitarnego, z całkowitym odrzuceniem demonicznej władzy, tragicznych skutków działań której doświadczył na sobie sam Daniił-Jawuczow-Charms podlegając niesprawiedliwemu aresztowaniu jakie kończy się dla niego wyjątkowo tragicznie.

\section{Literatura}

Bogaczyk-Vormayr M., Fałsz egzystencji. Człowiek w dziele Franza Kafki, „Humaniora. Czasopismo Internetowe" 2014, nr 1 (5), [online], http://humaniora. amu.edu.pl/sites/default/files/humaniora/Humaniora\%20nr\%205/Hum_1_ 2014_Bogaczyk.pdf, [08.06.2017].

Budrecka A., 2014, Koncepcja Boga w twórczości Franza Kafki, [w:] Żydzi wschodniej Polski. Seria II. W blasku i w cieniu historii, red. nauk. J. Ławski i B. Olech, Białystok, s. 339-354.

Duda K., 2010, Andriej Amalrik - rosyjski dysydent, Kraków.

Eslin M., 1969, The Theatre of the Absurd, New York.

Figes O., 2008, Szepty. Życie w stalinowskiej Rosji, przeł. W. Jeżewski, Warszawa.

Garlicki A., Codzienny stalinizm. Życie w stalinowskiej Rosji. Recenzja ksiazkki: Orlando Figes, „Szepty. Życie w stalinowskiej Rosji”, „Polityka” 2008, [online], http://www.polityka.pl/tygodnikpolityka/kultura/ksiazki/252504,1,recenzja -ksiazki-orlando-figes-szepty-zycie-w-stalinowskiej-rosji.read, [16.09.2016].

Frołow S., Andriej Wyszyński: sekrety bezwzględnego pomocnika Stalina. Tajemnica prokuratora Wyszyńskiego, „Polityka” 2016, nr 24, 7 czerwca, s. 62-65, [online], http://www.polityka.pl/tygodnikpolityka/historia/1663518,1,andriejwyszynski-sekrety-bezwzglednego-pomocnika-stalina.read, [23.09.2016].

Gracla J., 2001, Dramaturgia rosyjska przełomu XIX $i$ XX wieku w świetle przemian teatru w Europie, Katowice.

Grzywacz M., Zestanie do psychuszki. Historia najnowsza, „Gazeta wyborcza” 2015, [online], http://wyborcza.pl/alehistoria/1,121681,19079685,zeslanie-do -psychuszki-historia-najnowsza.html, [17.09.2016].

Jęsiak A., Harciarek M., Neuropsychologia. Jak choroba zmienia pacjenta, [online], http://www.poradnia.pl/neuropsychologia-jak-choroba-zmienia-pacjenta. html, [26.09.2016].

Kasperski E., Tragigroteska Kafki, „Tekstualia” 2008, nr 3(14), s. 19-34.

Kireńczuk T., Do teatru nie wchodzi się bezkarnie, „Gazeta teatralna” 2008, nr 8, s. 3 .

Kopaliński W., 1988, Stownik mitów i tradycji kultury, Warszawa, s. 999. 
Manifest Oberiu, tłum. Drawicz A., [w:] Tragiczna zabawa. Oberiu, czyli inna Rosja poetycka, wybrał i oprac. Drawicz A., tłum. Czech J., Dąbrowski W., Drawicz A., Fedecki Z., Jarecki A., Mandalian A., Pomorski A., Wirpsza W., Woroszylska N., Woroszylski W., Kraków 1991, s. 14.

Markowski M. P., 2015, Dialektyka zaciemnienia. Esej o biurokracji, „Dwutygodnik.com. Strona kultury", wyd. 167, [online], http://www.dwutygodnik.com /artykul/6106-dialektyka-zaciemnienia-esej-o-biurokracji.html, [09.06.2017].

Nabokov V., 1971, Tamte brzegi, przeł. Siemaszkiewicz E., Warszawa.

Neuropsychologia medyczna, red. nauk. Armstrong C. L., Morrow L., red. nauk. wyd. polskiego Harciarek M., tłum. Mroziak B., Warszawa 2014, t. 2.

Płoski A., Kobos A. M., Lektura Kafki przynosi pocieszenie, [online], http://www. zwoje-scrolls.com/kafka-ploski/aploskir_1.htm, [09.06.2017].

Shipley J. T., 1979, Dictionary of World Literary Terms, Forms, Technique, Criticism, Boston, [cyt. za:] Борисов С., 2007, Эстетика „черного юмора" в российской традиции, [в:] С. Б. Борисов, Человек. Текст. Культура, Шадринск, с. 101.

Starczak-Kozłowska K., ks. prof. Tischner J., Pytać pytajacych..., „Kwartalnik artystyczny" 1994, nr 1, s. 44-49.

Krajewska A., 1996, Dramat i teatr absurdu w Polsce, Poznań, [recenzja]: M. Sugiera „Pamiętnik literacki” 1999, nr 90/1, s. 226.

Tatarkiewicz A., Powrót do Kafki, „Przegląd” 2009, wyd. 42, [online], https://www. tygodnikprzeglad.pl/author/anna-tatarkiewicz/, [08.06.2017].

Woroszylski W., Z teki przekładów (G. Iwanow, D. Charms, N. Gorbaniewska, S. Awierincew), „Kwartalnik artystyczny” 1994, nr 1, s. 25.

Żak S., Teatr $i$ dramat w latach 20. w Rosji, "Gazeta teatralna” 2008, nr 8, s. 6.

Александров А., 1991, Эврика обэриутов, [в:] Александров А., Ванна Архимеда, Ленинград с. 21, 25.

Борисов С., 2007, Эстетика „черного юмора” в российской традииии, [в:] Борисов С. Б., Человек. Текст. Культура, Шадринск, с. 101-114.

Глоцер В., „Я думал о том, как прекрасно все первое!”, „Новый мир” 1988, № 4, c. $129-160$.

Манифест ОБЭРИУ, оформление Бахтерева И. [online], http://xapmc.gorodok. net/documents/1423/default.html, [09.06.2017].

Злобина А., Случай Хармса, или Оптический обман, „Новый Мир” 1999, № 2, [online], http://magazines.russ.ru/novyi_mi/1999/2/zlob.html, [29.09.2016].

Жаккар Ж. Ф., 1995, Даниил Хармс и конеи русского авангарда, Санкт-Петербург, с. 218-221.

Кобринский А., 2009, Даниил Хармс, Москва, с. 416-417.

Кусовац Е., Елизавета Бам: страх бытия, „Toronto Slavic Quarterly” 2016, nr 57, [online], http://sites.utoronto.ca/tsq/22/kusovac22.shtml, [17.09.2016].

Манифест ОБЭРИУ, [online], http://xapmc.gorodok.net/documents/1423/ default.html, [09.06.2017]. 
Мандельштам О., 1994, Мы живем, под собою не чуя страны, [в:] О. Мандельштам, Собрание сочинений в 4 томах, Москва, т. 3, с. 74 .

Остроухова Е., Кувшинов Ф., 2003, Псевдонимь Д. И. Хармса, [в:] „Странная” поэзия и „странная" проза, Москва, с. 230-245.

Сажин В., 1985, Литературные и Фольклорныее традиции в творчестве Д.И. Хармса, [в:] Литературный прочесс в развитии русской культурь XVIII-XX веков. Тезись научной конференции, Таллинн, [online], http:// www.d-harms.ru/library/literaturnie-i-folklornie-traditsii-v-tvorchestveharmsa.html, [26.09.2016].

Токарев Д., 2002, Курс на худшее: Абсурд как категория текста у Даниила Хармса и Сэмюэля Беккета, Москва.

Хармс Д., 1999, Елизавета Бам, [в:] Д. Хармс, Цирк Шардам, Санкт-Петербург.

Шульпяков Г., Хармс как страх, „Огонёк” 2013, № 26, с. 40.

TRAGICOMEDY OF THE ABSURD. ELIZABETH BAM DANIIL KHARMS. (REMINISCENCES IN THE MARGINS OF THE TRIAL BY FRANZ KAFKA)

S U M M A R Y

The main purpose of the analysis performed in this article is to point out the presence of an element of the absurd in Daniil Kharms'es works. The subject of authority-individual relation's absurdity is a relevant aspect of Kharms'es drama Elizabeth Bam. The author's creation refers to the motive of ridiculous arrest known from the Franz Kafka's novel The Trial. Both incidents make completely no sense at all. Neither of them has any argumentation or justification. The process, however, is not altogether identical. To highlight absurdity of the arrest Kharms reaches for literary devices like: satire, hyperbola, irony and even grotesque. 